\title{
Etiolation and indolbutyric acid in the Olea europaea cv. Maria
} da Fé minicuttings

\author{
Dianini Brum Frölech ${ }^{1}$, Maria Inez Lopes Fernandes de Barros ${ }^{1} \oplus$, Adriane Marinho de Assis ${ }^{1} \oplus$, \\ Márcia Wulff Schuch ${ }^{1} \mathbb{0}$

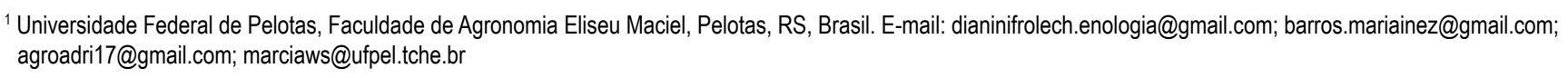

ABSTRACT: This study aims to evaluate the effect of etiolation and the usage of indolbutyric acid (IBA) in the propagation of Olea europaea cv. Maria da Fé minicuttings. The experimental outline is a completely randomized design, with a $2 \times 3$ bifactorial scheme [minicuttings from plants with and without etiolation and three concentrations of indolbutyric acid $(0,1,000$, and 2,000 mg $\left.\mathrm{L}^{-1}\right)$ ]. After 110 days, the following has been evaluated: percentage of survival, foliar retention and rooting, number of roots, length of the largest root, root dry matter mass and percentage of unrooted minicuttings with calluses. For the percentage of survival, foliar retention and rooting, number of roots and root dry matter mass, there has only been significance for IBA concentrations, and in general, the IBA $1,000 \mathrm{mg} \mathrm{L}^{-1}$ concentration provided the highest scores. For the length of the largest root and minicuttings with non-rooted callus, there has been interaction between treatments, with the lowest scores for callus formation in the minicuttings with etiolation and without IBA. It can be concluded that the minicutting of Olea europaea cv. Maria da Fé can be carried out without etiolation in the mother plants, using $1,000 \mathrm{mg} \mathrm{L}^{-1}$ of IBA.

Key words: auxin; olive tree; plant growth regulator; vegetative propagation; vermiculite

\section{Estiolamento e ácido indolbutírico na miniestaquia de Olea europaea cv. Maria da Fé}

RESUMO: O objetivo deste estudo foi avaliar o efeito do estiolamento e da utilização de ácido indolbutírico (AIB) na propagação de miniestacas de Olea europaea cv. Maria da Fé. O delineamento experimental foi o inteiramente casualizado, em esquema bifatorial $2 \times 3$ [miniestacas oriundas de plantas sem e com estiolamento e três concentrações de ácido indolbutírico $(0,1.000$ e $\left.2.000 \mathrm{mg} \mathrm{L}^{-1}\right)$ ]. Após 110 dias foram avaliadas: porcentagem de sobrevivência, de retenção foliar e de enraizamento, número de raízes, comprimento da maior raiz, massa de matéria seca das raízes e porcentagem de miniestacas com calos e não enraizadas. Para a porcentagem de sobrevivência, de retenção foliar, enraizamento, número de raízes e massa de matéria seca das raízes, houve significância apenas para as concentrações de AIB, sendo que, de maneira geral, a concentração de $1.000 \mathrm{mg} \mathrm{L}^{-1}$ de AIB proporcionou as maiores médias. Para o comprimento da maior raiz e miniestacas com calos e não enraizadas obtiveram-se interação entre os tratamentos, destacando-se a menor média para a formação de calos nas miniestacas com estiolamento e sem AIB. Conclui-se que a miniestaquia de Olea europaea cv. Maria da Fé pode ser realizada sem o estiolamento nas plantas matrizes, com uso de $1.000 \mathrm{mg} \mathrm{L}^{-1} \mathrm{de}$ AlB.

Palavras-chave: auxina; oliveira; regulador vegetal; propagação vegetativa; vermiculita 


\section{Introduction}

The olive tree (Olea europaea L.) belongs to the Oleaceae family, encompassing species distributed by tropical and temperate regions, and it is the only species of this family that produce edible fruits.

Considering the genetic variability and the long juvenile period, the sexual reproduction of the olive tree is not the most recommended for the commercial production of seedlings. In this sense, vegetative propagation is a viable technique because it maintains the genetic characteristics of the mother plants, and also because of the precocity of the production, being the minicutting the most utilized method (Coutinho et al., 2015). Moreover, this technique is of vital importance for the reduction of production costs (Kaim \& Bisht, 2017).

An adaptation of conventional cutting is the minicutting (Moreira et al., 2017) that is used in the production of not only O. europaea cv. Barnea (Moreira et al., 2017) and Arbequina (Casarin et al., 2017; Casarin et al., 2018), but it was also tested for the production of various fruit species such as soursop (Annona muricata L.) (Figueirêdo et al., 2013), 'pitangueira'(Eugenia uniflora L.) (Peña et al., 2015), and the acerola cherry tree (Câmara et al., 2016).

In order to optimize the production of seedlings through this method, some conditioning techniques can be adopted. Among them is the pre-treatment of the mother plants in a process called etiolation, where the development of the plant or part of it happens in the absence of light, resulting in overall elongated sprouts, with small leaves, and low level of chlorophyll, and high level of endogenous auxins (Fachinello et al., 2005). There aren't any records on the efficacy of etiolation in the minicutting of $O$. europaea cv. Maria da Fé, though.

Another alternative for enhancing the propagation by minicuttings is the usage of growth regulators, such as indolbutyric acid, that was used in the multiplication of $O$. europaea cv. Koroneiki (Penso et al., 2016), blackberry tree (Rubus spp.) (Hussain et al., 2014), amongst other fruit trees. From those studies, it is highlighted the importance to do research on the suitable concentration of IBA in the production through minicuttings, since the technique variates according to species and cultivation.

Given the above-mentioned, this study aimed to evaluate the propagation of Olea europaea cv. Maria da Fé minicuttings from the mother plants with and without etiolation, and submitted to different IBA concentrations.

\section{Materials and Methods}

The experiment was performed from May to September 2016 at the Federal University of Pelotas (UFPel) Lab of Fruit Plants Propagation, in the Capão do Leão campus, based in the municipality of Capão do Leão, state of Rio Grande do Sul, Brazil.

Five-year-old mother plants of Olea europaea cv. Maria da Fé, belonging to the germplasm bank of the Department of Phytotechny of the Eliseu Maciel Faculty of Agronomy (UFPel), were used, kept in an agricultural greenhouse in 90-liter vases, in a semi-hydroponic system, irrigated daily with nutritive solution, as formulated by Schuch \& Peil (2012).

The experimental outline is completely randomized in a bifactorial scheme of $2 \times 3$ [minnicutings from plants without and with etiolation, and three concentrations of indolbutyric acid $(0,1,000$ e 2,000 $\mathrm{mg} \mathrm{L}-1)]$, with five repetitions and 15 minicuttings per portion, in a total of 450 minicuttings.

One portion of the mother plants was submitted to etiolation during 110 days, with the utilization of a black plastic coverage on wooden support above the plants' top, covering them, but without touching them, while the remaining plants were kept in the same environment but without the plastic cover.

After this period, branches of the apical portion of the mother plants were collected for the preparation of the minicuttings with three to five $\mathrm{cm}$ of length, two gems and a pair of leaves cut in half. With the help of a scalpel, a superficial cut was made in the base of the minicuttings of $0.5 \mathrm{~cm}$ wide and long, to eliminate the physical barrier formed by rings of sclerenchyma (Fachinello et al., 2005). The minicutting bases were immersed for five seconds in a hydroalcoholic solution of IBA, according to the concentration adopted.

After the different treatments with IBA, the minicuttings were transplanted in Sanpack ${ }^{\circledR}(22 \times 14 \times 10 \mathrm{~cm})$ transparent articulated plastic trays, with five orifices in the basal part, to propitiate water draining. The trays were previously filled with a liter of vermiculite with medium granulometry, and with a wash bottle, we watered $500 \mathrm{~mL}$ of distilled water, on average, once a week, to keep the substrate humid. Next, they were kept at UFPel's vegetation house, in a controlled climate of $25 \pm 2{ }^{\circ} \mathrm{C}$. Also, the relative humidity of the air inside was an average of $90 \%$, registered by thermohygrometer.

After 110 days, the variables evaluated were the percentage of survival, foliar retention and rooting, the number of roots, length of the biggest root $(\mathrm{cm})$, mass of dry matter of the roots $(\mathrm{g})$, and percentage of minicuttingss with calluses and non-rooted.

Determining the length of the roots was calculated by a graduated ruler. The mass of root dry matter was obtained through kiln drying at $60^{\circ} \mathrm{C}$ to make the weight constant, using an analytical digital scale for weighing.

Also, a characterization of the physical and chemical properties of vermiculite was performed, as the $\mathrm{pH}$ in water in $1: 1$ the relation, electrical conductivity $\left(\mathrm{dS} \mathrm{m} \mathrm{m}^{-1}\right)$, and water retention capacity $\left(\mathrm{mL} \mathrm{L}^{-1}\right)$, according to Kämpf et. al. (2006) (Table 1).

Data were submitted to analysis of variance through the test $F(p \leq 0,05)$. Statistical significance verified, the effects of etiolated were compared through the test $t(p \leq 0,05)$ and the concentrations of IBA through the test of Duncan $(p \leq 0,05)$.

Table 1. Characterization of vermiculite substrate at 110 days of experiment installation. UFPel, Pelotas-RS, 2016.

\begin{tabular}{cccc}
\hline Substrate & pH & $\begin{array}{c}\text { EC } \\
\left(\mathrm{dS} \mathrm{m}^{-1}\right)\end{array}$ & $\begin{array}{c}\text { WRC } \\
\left(\mathrm{mL} \mathrm{L}^{-1}\right)\end{array}$ \\
\hline Vermiculite & 7.7 & 0.3 & 476.2 \\
\hline pH - Hydrogenionic potential; EC - Electrical conductivity; WRC - Water retention capacity.
\end{tabular}




\section{Results and Discussion}

For the percentage of survival, foliar retention and rooting, number of roots, and root dry matter mass, only the concentration of indolbutyric acid was significant (Table 2).

Regarding survival (\%) and foliar retention (\%), the minicuttings that were not treated with IBA, and the ones submitted to 0 and $1,000 \mathrm{mg} \mathrm{L}^{-1}$ of IBA, presented the highest scores and did not differ significantly (Table 2). Normally, the presence of leaves has the function of stimulating the rooting providing mainly hormones and carbohydrates; these last ones are important for survival for ensuring the best physiological conditions in the process of rooting.

The presence of leaves may help in the process of rooting because auxin is produced in the new leaves and gems and conducted with sugar and other nutritive substances for the bottom part of the plant, and accumulating in the base of the cut (Hartmann et al., 2002). And besides that, the production of photoassimilates from the leaves guarantees the necessary energy for vegetal maintenance and development (Taiz \& Zeiger, 2015).

Regarding rooting, the concentration of 1,000 e de 2,000 $\mathrm{mg} \mathrm{L}^{-1}$ IBA produced the highest percentages, 45.71 and 33.33 respectively, and did not differ significantly (Table 2). Similar to this experiment, Moreira et al. (2017) described that the highest IBA concentrations tested $(2,000$ e 3,000 $\mathrm{mg} \mathrm{L}^{-1}$ ) produced the highest rates of rooting in $O$. europaea $\mathrm{cV}$. Barnea. Besides the concentration of IBA, another factor related to rooting of the minicuttings is the physiological condition of the mother plant at the moment of cutting the material used in propagation, taking into consideration factors such as age, sanity, nutritional conditions, and consistency of branches (Picolotto et al., 2015).

Regarding the number of roots per minicutting, the highest score was obtained with the application of $1,000 \mathrm{mg} \mathrm{L}^{-1}$ of IBA, reaching a total of 19.63 (Table 2). Câmara et al. (2016) mentioned that the translocation of carbohydrates from the leaves to the base of the minicutting, as well as the production of auxins and other cofactors of rooting, may have promoted stimulation to root initiation in acerola trees (Malpighia glabra L.), and such fact may have cooperated for the higher number of roots per minicutting. In this study, the minicuttings that were not treated with IBA presented the lowest number of roots, in spite of presenting higher foliar retention, together with the concentration of $1,000 \mathrm{mg} \mathrm{L}^{-1}$.
It is possible to observe that for the percentage of rooting and number of roots (Table 2 ), the lowest scores were obtained by the minicutting that were not treated with IBA. On the other hand, the highest percentage of survival was verified in this condition, alongside with the concentration of 1,000 $\mathrm{mg} \mathrm{L}^{-1}$ IBA. We highlight that the survival of the minicuttings is of the highest importance; however, for the success in the production of seedlings, the emission of roots is fundamental. Such results are in accordance with the ones obtained by Moreira et al. (2017) with O. europaea cv. Barnea.

Both 1,000 and $2,000 \mathrm{mg} \mathrm{L}^{-1}$ of IBA produced the highest scores of root dry matter mass $(0.02 \mathrm{~g})$ and did not differ significantly from one another (Table 2). According to Fachinello et al. (2005), the increase of exogenous auxin concentration in the stake provokes a stimulating effect on the development of roots up to a maximum score, from which any increase has an inhibitive effect.

Regarding the length of the longest root and percentage of minicuttings with non-rooted calluses, it has occurred interaction among the tested factors (Table 3).

For the length of the longest root, when comparing etiolation in the different concentrations, only statistic difference happened for the AIB concentration of $1,000 \mathrm{mg}$ $\mathrm{L}^{-1}$, where a higher value was verified for the minicuttings of etiolated plants, differing from the collected minicuttings of plants without etiolation. By analyzing only, the AIB concentrations, the longest length of roots was verified for AIB concentrations of 1,000 and $2,000 \mathrm{mg} \mathrm{L}^{-1}$ for the minicuttings from mother plants with etiolated branches, differing from the ones that haven't received the AIB application.

Table 3. Length of the longest root $(\mathrm{cm})$ and minicuttings with non-rooted calluses (\%) of $O$. europaea cv. Maria da Fé, regarding etiolation and the different AIB concentrations. UFPel, Pelotas-RS, 2016.

\begin{tabular}{|c|c|c|c|}
\hline \multirow{2}{*}{ Etiolation } & \multicolumn{3}{|c|}{ AlB concentration (mg L-1) } \\
\hline & 0 & 1,000 & 2,000 \\
\hline & \multicolumn{3}{|c|}{ Length of the longest root $(\mathrm{cm})$} \\
\hline Without & $2.63 \pm 1.08 \mathrm{aAB}^{1 /}$ & $0.92 \pm 0.72 \mathrm{bB}$ & $4.13 \pm 0.19 \mathrm{aA}$ \\
\hline \multirow[t]{2}{*}{ With } & $0.28 \pm 0.28 \mathrm{aB}$ & $3.88 \pm 0.72 \mathrm{aA}$ & $3.40 \pm 0.76 \mathrm{aA}$ \\
\hline & \multicolumn{3}{|c|}{ Minicuttings with non-rooted calluses (\%) } \\
\hline Without & $10.67 \pm 1.63 \mathrm{aA}$ & $1.33 \pm 1.33 \mathrm{aB}$ & $1.33 \pm 1.33 \mathrm{aB}$ \\
\hline With & $0.00 \pm 0.00 \mathrm{bA}$ & $2.67 \pm 1.63 a \mathrm{~A}$ & $1.33 \pm 1.33 \mathrm{aA}$ \\
\hline
\end{tabular}

${ }^{1 /}$ Averages ( \pm standard error) with same capital letter on the column do not differ from each other through the test $\mathrm{t}(p>0,05)$, comparing etiolation in every concentration of AIB and capital letter on the same line do not differ from each other through the test of Duncan $(p>0,05)$, comparing the concentrations of AIB in each form of etiolation.

Table 2. Survival (\%), foliar retention (\%), rooting (\%), number of roots and root dry matter mass (g) of minnicuttings of $O$. europaea cv. Maria da Fé in different indolbutyric acid (IBA) concentrations. UFPel, Pelotas-RS, 2016.

\begin{tabular}{|c|c|c|c|c|c|c|}
\hline \multirow{2}{*}{ Variables } & \multicolumn{6}{|c|}{ Concentrations of IBA (mg L-1) } \\
\hline & 0 & & 1,000 & & 2,000 & \\
\hline Survival (\%) & $86.67 \pm 0.73$ & $a^{1 / /}$ & $79.20 \pm 0.44$ & a & $33.33 \pm 0.62$ & $b$ \\
\hline Foliar retention (\%) & $84.47 \pm 0.75$ & a & $75.00 \pm 0.73$ & a & $33.33 \pm 0.62$ & $b$ \\
\hline Rooting (\%) & $9.63 \pm 2.75$ & $b$ & $45.71 \pm 8.16$ & a & $33.33 \pm 6.36$ & a \\
\hline Number of roots & $2.56 \pm 0.88$ & $\mathrm{C}$ & $19.63 \pm 1.87$ & a & $9.00 \pm 2.36$ & $b$ \\
\hline Root dry matter mass (g) & $0.00 \pm 0.00$ & $\mathrm{~b}$ & $0.02 \pm 0.00$ & $\mathrm{a}$ & $0.02 \pm 0.00$ & a \\
\hline
\end{tabular}

${ }^{1 / A v e r a g e ~(~} \pm$ standard error) followed by the same letter in the line do not differ through the Duncan test $(p>0,05)$, comparing the different IBA concentrations. 
Regarding the minicuttings with calluses and non-rooted, when comparing the etiolation factor, it was obtained only statistic difference only for the minicuttings that weren't treated with AIB, where the plants that weren't treated with etiolation presented the highest percentage (Table 3). On the AIB concentrations comparison, without the etiolation of the mother plants, the AIB concentration of $0 \mathrm{mg} \mathrm{L}^{-1}$ produced the highest value, and the minicuttings from etiolated plants, there wasn't any difference between the concentrations.

According to Penso et al. (2016), the callus formation capacity is an indication of the transformation and differentiation of tissue capacity. As the conversion of plant tissues into calluses is associated with the hormonal balance between auxins and cytokines in cells, probably the highest AIB concentrations have caused hormonal unbalance and, therefore, reduced callogenesis (Colombo et al., 2018). To Silva et al. (2012), it is interesting that the formation of calluses is low once it may reflect in a higher percentage of root-producing minicuttings.

To sum up, despite the alleged advantages of the etiolation technique (Fachinello et al., 2005), under the conditions we have described in this study, most of the evaluated variables haven't presented statistic significance between the minicuttings forms of $O$. europaea cv. Maria da Fé collected from mother plants with or without etiolation. Being so, such pre-treatment is unnecessary taking into consideration the time, work and materials it takes for the plants to remain in the absence of light. On the other hand, the AIB concentration of $1,000 \mathrm{mg} \mathrm{L}^{-1}$ was the most indicated for the treatment of the minicuttings, regarding their rooting and the production of seedlings.

\section{Conclusion}

The production of seedlings through the minicuttings of Olea europaea cv. Maria da Fé can be performed without the use of the technique of mother plants etiolation, with the application of $1,000 \mathrm{mg} \mathrm{L}^{-1}$ of AIB.

\section{Acknowledgments}

To the Coordination for the Improvement of Higher Education Personnel (CAPES) and the National Council for Scientific and Technological Development (CNPq), for the concession of scholarships.

\section{Literature Cited}

Câmara, F.M.M.; Carvalho, A.S.; Mendonça, V.M.; Paulino, R.C.; Diógenes, F.E.P. Sobrevivência, enraizamento e biomassa de miniestacas de aceroleira utilizando extrato de tiririca. Comunicata Scientiae, v.7, n.1, p.133-138, 2016. https://doi. org/10.14295/cs.v7i1.1372.

Casarin, J.V.; Moreira, R.M.; Raasch, C.G.; Timm, C.R.F.; Schuch, M.W. Productivity and rooting of olive mini-cuttings grown in a clonal mini-garden according to season. Comunicata Scientiae, v.8, n.4, p.537-543, 2017. https://doi.org/10.14295/cs.v8i4.2330.
Casarin, J.V.; Ramm, A.; Raasch, C.G.; Timm, C.R.F.; Schuch, M.W. Rooting of olive minicuttings at different seasons grown in clonal minigarden. Comunicata Scientiae, v.9, n.1, p.41-49, 2018. https://doi.org/10.14295/cs.v9i1.2525.

Colombo, R.C.; Assis, A.M. de; Favetta, V.; Yamamoto, L.Y.; Roberto, S.R. Collect seasons, indolebutyric acid and substrates on rooting of 'Bengal' lychee cuttings. Journal of Agricultural Science, v. 10, n. 5, p.1-7, 2018. https://doi.org/10.5539/jas.v10n5p338.

Coutinho, E.F.; Jorge, R.O.; Haerter, J.A.; Costa, V.B. Oliveira: aspectos técnicos e cultivo no Sul do Brasil. Brasília: Embrapa, 2015. 181p.

Fachinello, J.C.; Hoffmann, A.; Nachitgal, J.C. Propagação de plantas frutíferas. 1.ed. Brasília: Embrapa Informação Tecnológica, 2005. 221 p.

Figueirêdo, G.R.G.; Vilasboas, F.S.; Oliveira, S.J.R.; Sodré, G.A.; Sacramento, C.K. Propagação da gravioleira por miniestaquia. Revista Brasileira Fruticultura, v.35, n.3, p.860-865, 2013. https:// doi.org/10.1590/S0100-29452013000300024.

Hartmann, H.T.; Kester, D.E.; Davies Junior, F.T.; Geneve, R.L. Plant propagation: principles and practices. 7.ed. New Jersey: Prentice Hall, 2002. 880 p.

Hussain, I.; Assis, A.M. de; Yamamoto, L.Y.; Koyama, R.; Roberto, S.R. Indole butyric acid and substrates influence on multiplication of blackberry 'Xavante'. Ciência Rural, v.44, n.10, p.1761-1765, 2014. https://doi.org/10.1590/0103-8478cr20131204.

Kaim, J.C.; Bisht, V.K. Rooting of Olive cuttings (Olea europaea L.) cV. Pendolino and Frontoio in relation to the propagation medium. Advance Pharmaceutical Journal, v. 2, n. 2, p. 69-73, 2017. http:// www.apjonline.in/uploaded/p35.pdf. 28 Mar. 2019.

Kämpf, N.A.; Takane, R.J.; Siqueira, P.T.V. Floricultura: técnicas de preparo de substratos. Brasília: LK Editora e Comunicação, 2006. v.1, 132 p.

Moreira, R.M.; Silva, J.B. da; Ramm, A.; Schuch, M.W.; Fagundes, C. de M.; Maciejewski, P.; Tomaz, Z.F.P. Ácido indolbutírico no enraizamento de miniestacas de oliveira 'Barnea'. Congrega Urcamp, p.1164-1174, 2017. http://trabalhos.congrega.urcamp. edu.br/index.php/14jpgp/article/view/1803. 28 Mar. 2019.

Peña; M.L.P.; Zanette; F.; Biasi, L.A. Época de coleta e ácido indolbutírico no enraizamento de miniestacas de pitangueira. Semina: Ciências Agrárias, v.36, n.5, p.3055-3068, 2015. https:// doi.org/10.5433/1679-0359.2015v36n5p3055.

Penso, G.A.; Sachet, M.R.; Maro, L.A.C.; Patto, L.S.; Citadin, I. Propagação de oliveira 'Koroneiki' pelo método de estaquia em diferentes épocas, concentrações de AIB e presença de folhas. Revista Ceres, v.63, n.3, p.355-360, 2016. https://doi. org/10.1590/0034-737X201663030012.

Picolotto, L.; Vignolo, G.K.; Pereira, I. dos S.; Goncalves, M.A.; Antunes, L.E.C. Enraizamento de estacas de amoreira-preta em função da adubação nitrogenada na planta matriz. Revista Ceres, v.62, n.3, p.294-300, 2015. https://doi.org/10.1590/0034-737X201562030009.

Schuch, M.W.; Peil, R.M.N. Soilless cultivation systems: A new approach in fruit plants propagation in southern Brazil. Acta Horticulturae, v.952, p.877-883, 2012. https://doi.org/10.17660/ ActaHortic.2012.952.111.

Silva, S.S. da; Klosowski, A.C.; Koyama, R.; Fabri, C.A.; Gomes, L.L.; Zuffellato-Ribas, K.C. Enraizamento de estacas de Jasminum polyanthum tratadas com ácido indolbutírico. Scientia Agraria, v.13, n.1, p.17-20, 2012. https://doi.org/10.5380/rsa.v13i1.40855.

Taiz, L.; Zeiger, E. Fisiologia vegetal. 5.ed. Porto Alegre: Artmed, 2015. $888 p$. 